\title{
PERSEPSI ANALIS KARTU KREDIT TENTANG RESIKO KARTU KREDIT PADA BANK KONVENSIONAL DAN BANK SYARIAH
}

\begin{abstract}
This study aimed to compare the perception of risk analysts credit card at conventional banks and Islamic banks, case studies on the BNI and BNI Syariah in Semarang which includes the process of risk management application, credit card risk identification and appearing stagnant credit card. This study was measured using a questionnaire method is to assess the perception of risk analysts credit card at conventional banks and Islamic banks. Then to compare the perception of risk analysts credit card at conventional banks and Islamic banks performed different tests using the Mann - Whitney test because the data presented is not normal, by ten respondents. The results of the research analyst 's perception of the risk of credit card shows that on each item tested on conventional banks are superior to Islamic banks when viewed from the mean rank in Mann Whitney rank output, but this difference was not significant, so that could be said about the credit card analyst perception risk credit card at conventional banks and Islamic banks are the same.
\end{abstract}

Keyword: Credit analysts, conventional bank, islamic bank, accounting information islamic perspective.

\section{PENDAHULUAN}

Kartu kredit merupakan alat pembayaran pengganti uang tunai yang dapat digunakan oleh konsumen untuk ditukarkan dengan barang dan jasa yang diinginkannya di tempat-tempat yang dapat menerima pembayaran dengan menggunakan kartu kredit (merchant).Pengertian kartu kredit dalam pasal 1 angka 4 Peraturan Bank Inonesia Nomor 7/52/PBI/2005 sebagaimana diubah dengan Peraturan Bank Indonesia Nomor 10/8/PBI/2008 Tentang Penyelenggaraan Kegiatan Alat Pembayaran Dengan Menggunakan Kartu, yaitu:

"Kartu Kredit adalah Alat Pembayaran Dengan Menggunakan Kartu yang dapat digunakan untuk melakukan pembayaran atas kewajiban yang timbul dari suatu kegiatan ekonomi, termasuk transaksi pembelanjaan dan/atau untuk melakukan penarikan tunai dimana kewajiban pembayaran pemegang kartu dipenuhi terlebih dahulu oleh acquirer atau penerbit, dan pemegang kartu berkewajiban melakukan pelunasan kewajiban pembayaran tersebut pada waktu yang disepakati baik secara sekaligus (charge card) ataupun secara angsuran."

Dibandingkan dengan jenis-jenis kredit yang ditawarkan dunia perbankan, kartu kredit merupakan jenis kredit yang paling mudah dan cepat disetujui. Syaratnya sederhana yaitu fotocopi KTP dan slip gaji atau surat keterangan penghasilan bagi karyawan sedangkan SIUP, SPT dan NPWP merupakan syarat bagi pengusaha. Selain itu, kelebihan lain dari penggunaan kartu kredit adalah lingkup penggunaannya yang sangat luas, dari transaksi kecil sampai transaksi bervolume besar. Hal ini sangat berguna bagi masyarakat, terutama bagi mereka yang sering melakukan perjalanan, baik untuk bisnis maupun wisata karena kartu kredit juga dapat digunakan untuk melakukan transaksi diberbagai negara yang menerima pembayaran dengan kartu kredit. 
Dengan kartu kredit, sistem pembayaran menjadi lebih praktis, cepat, aman dan nyaman.

Pengelolaan kartu kredit bagi sebuah bank perlu dilakukan agar prosesnya berjalan dengan baik dan meminimalkan default atau macet.Melakukan pengelolaan kartu kredit berarti melaksanakan fungsi-fungsi manajemen, dimana dalam mengelola atau mengatur sejumlah limit kartu kredit perlu dilakukan perencanaan yang matang.Kemudian setelah direncanakan maka diorganisasikan, agar perencanaan tersebut lebih terarah. Organisasi sangat penting karena merupakan tempat bagi perusahaan dalam mencapai tujuannya, sedangkan manajemen merupakan alat untuk mencapai tujuan tersebut.Terakhir perlu dikendalikan dan dilakukan pengawasan agar pelaksanaannya sesuai dengan rencana yang telah ditetapkan.Dengan dilakukannya pengelolaan kartu kredit secara professional diharapkan dapat meningkatkan kualitas aset, likuiditas dan profitabilitas bank, karena kualitas aset, tingkat likuiditas dan profitabilitas yang tinggi menunjukkan kinerja perbankan yang tinggi pula.Oleh karena itu bank sangat membutuhkan adanya seorang analis kredit, yang berfungsi menganalisis permohonan kartu kredit dari nasabah.

Menurut Indra Prasetyo (2008), dalam penelitiannya mengenai Analisis KinerjaKeuangan BankSyari'ah danBankKonvensional di Indonesia menemukan bahwa Rasio keuangan yang membedakan adalah rasio NPM dan LDR, Pada rasio NPM bank konvensional yang menerapkan sistem bunga lebih pasti dalam perolehan laba daripada pada bank syari'ah yang menggunakan sistem bagi hasil dan Pada Rasio LDR bank syari'ah lebih efektif dibandingakan bank konvensional.

Menurut Widyanti Khaeruddin (2012) dalam penelitiannya tentang analisis sistem kartu kredit syariahpada PT Bank BNISyariah menemukan bahwa sistem kartu kredit syariahnya telah berdasarkanpada fatwa DSN No. 54/DSN-MUI/X/2006 dan surat persetujuan dari Banklndonesia No. 10/337/DPbs tanggal 11-03-2008. Sehingga dapat dikatakanbahwa sistem kartu kredit yang diterapkan oleh PT Bank BNI Syariah telahsesuai dengan apa yang ditetapkan dalam fatwa

Menurut Samiah Harhara (2009) dalam penelitiannya tentang persepsi analis kredit/pembiayaan tentang resiko kredit pada bank konvensional dan bank syariah menemukan bahwa tidak terdapat signifikan antara persepsi analis kredit bank syariah dan analis kredit bank konvensional terhadap proses penerapan manajemen resiko dan terhadap identifikasi resiko kredit, namun terdapat perbedaan signifikan antara analis kredit bank syariah dan bank konvensional terhadap timbulnya kredit macet.

Menurut Marissa Ardiyana (2011) dalam penelitiannya mengenai AnalisisPerbandingan Kinerja Keuangan Bank Syari'ah Dan Bank Konvensional Sebelum, Selama, Dan Sesudah Krisis Global Tahun 2008 Dengan Menggunakan Metode CAMEL (Studi Kasus Pada PT Bank Syari'ah Mandiri Dan PT Bank Mandiri Tbk), ditemukan bahwa Keseluruhan rasio bank dinyatakan sehat, nilai rasio bank Mandiri lebih unggul dari pada Bank Syari'ah Mandiri, namun untuk pertumbuhan rasio, Bank Syari'ah Mandiri lebih unggul dari pada Bank Mandiri. Perbedaan yang signifikan adalah pada rasio CAR, ROA, dan LDR.Pada masa krisis global Bank Syari'ah Mandiri mampu mempertahankan nilai maupun pertumbuhan rasionya dibandingkan Bank Mandiri.

\section{KAJIAN PUSTAKA DAN PENGEMBANGAN HIPOTESIS}

Pemberian fasilitas kartu kredit merupakan bagian penting bagi perkembangan dunia usaha. Para 
ahli ekonomi islam sepakat bahwa keberadaan lembaga permodalan tetap penting untuk menjalankan perekonomian sehingga pemecahannya adalah dengan membuka alternative lembaga keuangan yang dijalankan tidak dengan menggunakan sistem bunga melainkan sistem bagi hasil dan jual beli. Dalam sistem ini pemberian dana kepada pelaku usaha dipandang sebagai investasi terhadap usaha sehingga resiko kegagalan usaha menjadi tanggung jawab kedua belah pihak.

Analisis kredit memiliki dua tujuan, yaitu tujuan umum dan tujuan khusus.Tujuan umum analisis kredit adalah pemenuhan jasa pelayanan terhadap kebutuhan masyarakat dalam rangka mendorong dan melancarkan perdagangan, produksi, jasa-jasa bahkan kesemuanya yang ditunjukkan untuk meningkatkan taraf hidup masyarakat.Sedangkan tujuan khusus analisis kredit adalah untuk menilai kelayakan usaha calon debitur untuk menekan resiko akibat tidak terbayarnya pembiayaan dan untuk menghitung kebutuhan pembiayaan yang layak. Dalam proses pengambilan keputusan tersebut, analis kredit menggunakan informasi akuntansi sebagai informasi utama.

\section{Pengertian Bank Konvensional}

Bank konvensional dapat didefinisikan seperti pada pengertian bank umum pada pasal 1 ayat 3 UndangUndang No. 10 tahun 1998 dengan menghilangkan kalimat "dan atau berdasarkan prinsip syariah", yaitu bank yang melaksanakan kegiatan usaha secara konvensional yang dalam kegiatannya memberikan jasa dalam lalu lintas pembayaran. Dimana penghimpunan dana maupun dalam rangka penyaluran dananya memberikan dan mengenakan imbalan berupa bunga atau sejumlah imbalan dalam persentase tertentu dari dana untuk suatu periode tertentu.

Keuntungan utama dari bisnis perbankan yang berdasarkan prinsip konvensional diperoleh dari selisih bunga simpanan yang diberikan kepada penyimpan dengan bunga pinjaman atau kredit yang disalurkan. Keuntungan dari selisih bunga di bank dikenal dengan istilah spread based. Apabila suatu bank mengalami kerugian dari selisih bunga, dimana suku bunga simpanan lebih besar dari suku bunga kredit, maka istilah ini dikenal dengan namanegatif spread.

\section{Pengertian Bank Syariah}

Perbankan syariah dalam peristilahan internasional dikenal sebagai/slamic Banking atau juga disebut dengan interest-free banking. Peristilahandengan menggunakan kata Islamic tidak dapat dilepaskan dari asalusul sistemperbankan syariah itu sendiri.Menurut Muhammad (2005:13):Bank Islam atau selanjutnya disebut dengan Bank Syariah adalah bank yangberoperasi dengan tidak mengandalkan pada bunga. Bank Islam adalahlembaga keuangan yang usaha pokoknya memberikan pembiayaan dan jasa-jasalainnya dalam lalu lintas pembayaran serta peredaran uang yangpengoperasiannya disesuaikan dengan prinsip syariat Islam.

\section{Fungsi Bank Syariah}

Dalam beberapa literatur perbankan syari'ah, bank syari'ah dengan beragam skema transaksi yang dimiliki dalam skema non-riba memiliki setidaknya empat fungsi (Sumintro dalam Ardiyana, 2011), yaitu: 
1. Fungsi Manajer Investasi

2. Fungsi Investor

3. Fungsi Sosial

4. Fungsi Jasa Keuangan

Islam mengharamkan bunga dan menghalalkan bagi hasil. Keduanya memberikan keuntungan, tetapi memiliki perbedaan mendasar sebagai akibat adanya perbedaan antara investasi dan pembungaan uang (lihat tabel 2.2). Dalam investasi, usaha yang dilakukan mengandung risiko, dan karenanya mengandung unsur ketidakpastian. Sebaliknya, pembungaan uang adalah aktivitas yang tidak memiliki risiko karena adanya persentase suku bunga tertentu yang ditetapkan berdasarkan besarnya modal.

\section{Resiko Bank}

Resiko bank diartikan sebagai ketidakpastian yang dihadapi bankir dalam berbagai peritiwa. Untuk mencapai memperoleh kemungkinan laba tertinggi, bankir harus berkonsentrasi mengolah 6 resiko sebagai berikut:

1. Resiko Likuiditas

2. Resiko Kredit

3. Resiko Pasar

4. Resiko Tingkat Bunga

5. Resiko Pendapatan

6. Resiko Keamanan

\section{Pengukuran Resiko Kartu Kredit}

Sistem pengukuran resiko kredit sekurang-kurangnya mempertimbangkan tentang:

(1) Karakteristik setiap jenis transaksi resiko kredit, kondisi, keuangan debitur serta persyaratan dalam perjanjian kredit seperti dalam jangka waktu dan tingkat bunga;

(2) Jangka waktu kredit dikaitkan dengan perubahan potensial yang terjadi di pasar;

(3) Aspek jaminan,agunan dan/atau garansi;

(4) Potensi terjadinya kegagalan membayar, kamampuan bank untuk menyerap potensi kegagalan.

\section{Pemantauan Resiko Kartu Kredit}

Bank harus mengembangkan dan menerapkan sistem informasi dan prosedur untuk memantau kondisi setiap debitur dan counterparty pada seluruh portofolio kredit bank. Sistem pemantauan resiko kredit sekurang-kurangnya memuat ukuran-ukuran dalam rangka:

(1) Memastikan bahwa bank mengetahui kondisi kauangan terakhir dari debitur atau counterparty;

(2) Memantau kepatuhan terhadap persyaratan dalam perjanjian kredit atau kontrak transaksi resiko kredit;

(3) Menilai kecukupan anggunan dibandingkan dengan kewajiban debitur atau counterparty;

(4) Mengindentifikasikan ketidakpastian pembayaran dan mengklasifikasikan kredit bermasalah secara 
tepat waktu;

(5) Menangani dengan cepat kredit bermasalah

\section{Sistem Informasi Manajemen Resiko Kartu Kredit}

Dalam rangka meningkatkan efektifitas proses pengukuran resiko kredit, bank harus memiliki sistem informasi manajemen yang menyediakan data dan laporan secara akurat dan tepat waktu untuk mendukung pengambilan keputusan oleh direksi dan pejabat lainnya.Sistem informasi manajemen tersebut juga harus menghasilkan laporan atau informasi dalam rangka pemantauan eksposur actual terhadap limit yang ditetapkan dalam pelampauan eksposur limit resiko yang perlu mendapatkan perhatian dari direksi.

\section{Analisis, Persetujuan dan Pencatatan Kartu Kredit}

Prosedur pengambilan keputusan untuk pinjaman dan atau komitmen, khususnya apabila melalui pendelegasian wewenang, harus diformalkan secara jelas sesuai dengan karakteristik bank serta harus didukung oleh sistem yang dimiliki oleh bank.Bank harus memastikan bahwa kerangka kerja atau mekanisme kepatuhan prosedur pendelagasian dalam pengambilan keputusan pemberian kredit dan atau komitmen terdapat pemisahan fungsi antara yang melakukan persetujuan, analisis, dan administrsi kredit.

Dalam mengembangkan sistem administrasi kredit, bank harus memastikan:

1. Efisiensi dan efektivitas operasional adminitrasi kredit, termasuk pemantuan dokumentasi, persyaratan kontrak, perjanjian kredit (legal aspecy), dan pengikatan agunan;

2. Akurasi dan ketetapan waktu informasi yang diberikan untuk sistem informasi manajeman;

3. Pemisahan fungsi/ tugas (segregation of dutles) yang layak;

4. Kelayakan pengendalian seluruh prosedur back office;dan

5. Kepatuhan terhadap kebijakan dan prosedur intern tertulis serta ketentuan yang berlaku.

\section{Hipotesis Penelitian}

Perumusan hipotesis dari beberapa faktor yang diperkirakan dapat mempengaruhi nilai pada bank adalah sebagai berikut:

H1 : Tidak terdapat perbedaan secara signifikan antara persepsi analis kartu kredit bank konvensional dan bank syariah terhadap proses penerapan manajemen resiko kartu kredit.

$\mathrm{H} 2$ : Tidak terdapat perbedaan secara signifikan antara persepsi analis kartu kredit bank konvensional dan bank syariah terhadap identifikasi resiko kartu kredit.

H3 : Tidak terdapat perbedaan secara signifikan antara persepsi analis kartu kredit bank konvensional dan bank syariah terhadap timbulnya kartu kredit macet. 


\section{Metode Penelitian}

\section{Metode Pengumpulan Data}

a. Studi Pustaka

Pengumpulan data melalui studi pustaka dilakukan dengan mengkaji buku-buku atau literatur dan jurnal ilmiah untuk memperoleh landasan teoritis yang kuat dan menyeluruh tentang analis kartu kredit terutama pada bank konvensionaldan bank syariah.

b. Pengiriman Kuesioner

Pengiriman kuesioner dilakukan dengan menyebarkan kuesioner kepada analis kartu kredit pada BNI dan BNI Syariah yaitu analis kredit untuk mengumpulkan data primer.

\section{Teknik Analisis}

\section{Kuantitatif}

Teknik analisis yang digunakan dalam menganalisis data penelitian ini adalah menggunakan analisis kuantitatif. Dimana analisis kuantitatif adalah study yang bertujuan untuk mencari uraian secara menyeluruh, teliti dan komprehensif berdasarkan data empiris. Suatu permasalahan yang diselesaikan dengan pendekatan kuantitatif, seorang analis akan berkonsentrasi pada fakta kuantitatif atau data yang berhubungan dengan masalah dan selanjutnya membuat model matetik yang menjelaskan tujuan, hambatan dan lain-lainyang berhubungan dengan permasalahan, kemudian dengan satu atau beberapa metode lainnya, analisnya akan memberikan rekomendasi berdasarkan data kuantitatif tersebut.

\section{Pengujian Hipotesis}

Pengujian hipotesis dimaksudkan untuk mengetahui ada tidaknya perbedaan rata-rata diantara dua kelompok sampel.Karena diantara masing-masing kelompok sampelyang diuji saling independen maka pengujiannya dilakukan dengan menggunakan alat analisis Mann Whitney U-test untuk data yang tidak terdistribusi normal.Langkah pertama adalah memasukkan hasil jawaban kuesioner-kuesioner yang telah didapat kedalam Software Microsoft Excel XP kemudian dikonversi ke Software SPSS versi 21,0untuk selanjutnya dianalisa menggunakan uji statistik.

Uji ini digunakan karena data independen yang digunakan dalam penelitian ini hanya ada 2. Pengambilan keputusan:

1. Jika probabilitas < 0,05 maka HO ditolak, ada perbedaan signifikan terhadap proses penerapan manajemen resiko kartu kredit, identifikasi resiko kartu kredit dan timbulnya kartu kredit macet pada bank konvensional dan bank syariah.

2. Jika probabilitas $>0,05$ maka $\mathrm{HO}$ diterima, tidak ada perbedaan signifikan terhadap proses penerapan manajemen resiko kartu kredit, identifikasi resiko kartu kredit dan timbulnya kartu kredit macet pada bank konvensional dan bank syariah. 


\section{Profil Responden}

Penelitian ini menggunakan dua kelompok responden yaitu analis kartu kredit BNI konvensional dan analis kartu kredit BNI Syariah. Sampel responden penelitian ini terdiri dari 5 (lima) analis kartu kredit pada BNI konvensional dan 5 (lima) analis kartu kredit pada BNI Syariah yang berkantor pusat di Semarang.

Penyebaran kuesioner dilakukan pada saat yang bersamaan dan pengambilan kuesioner pada saat yang sama disaat penyebaran kuesioner. Kuesioner yang disebarkan kepada sampel analis kartu kredit bank konvensional sebanyak 5 buah. Kuesioner yang kembali 5 buah sehingga tingkat pengembalian adalah $100 \%$. Kuesioner yang disebarkan kepada sampel analis kartu kredit bank syariah sebanyak 5 buah.Kuesioner yang kembali 5 buah sehingga tingkat pengembalian adalah 100\%. Berikut ini adalah rincian responden penelitin. Data demografi responden yang digunakan dalam penelitian yaitu, jenis kelamin dan lama bekerja.

Berdasarkan tabel responden, dapat dijelaskan bahwa lama bekerja responden sebagai analis kartu kredit kurang dari 5 tahun ada 5 orang. Responden dengan lama bekerja sebagai analis kartu kerdit antara 5 tahun sampai 10 tahun ada 4 orang, sedangkan responden dengan lama bekerja sebagai analis kartu kredit lebih dari 10 tahun ada 1 orang.

\section{Hasil:}

1. Proses Penerapan Manajemen Resiko Kartu Kredit

Item manajemen resiko kartu kredit dari tabel 4.5 ditemukan Statistik Uji = Asymp. Sig. (2-tailed) =0,592. Karena Asymp. Sig. (2-tailed) =0,592>a = 5\% maka H0 diterima. Ini berarti tidak terdapat perbedaan pada aspek proses penerapan manajemen resiko kartu kredit antara bank konvensional dan bank syari'ah. Aspek manajemen resiko kartu kredit pada BNI adalah sama denganBNISyariah karena nilai "mean rank" pada output Mann Whitney Ranks 6,00 sedangkan nilai mean rankpadaBNI Syariah sebesar 5,00, sehingga tidak terdapat perbedaan signifikan.

2. Identifikasi Resiko Kartu Kredit

Item identifikasi resiko kartu kreditDari tabel 4.5 ditemukan Statistik Uji = Asymp. Sig. (2-tailed) =0,461. Karena Asymp. Sig. (2-tailed) =0,461> a = 5\% maka H0 diterima. Ini berarti tidak terdapat perbedaan aspek identifikasi resiko kartu kredit antara BNI dan BNI Syariah.Aspek identifikasi kartu kredit pada BNI adalah sama denganBNISyariah karena nilai "mean rank" pada output Mann Whitney Ranks 4,80 sedangkan nilai mean rankpadaBNI Syariah sebesar 6,20, sehingga tidak terdapat perbedaan signifikan.

\section{Timbulnya Kartu Kredit Macet}

Item timbulnya kartu kredit macet dari tabel 4.5 ditemukan Statistik Uji = Asymp. Sig. (2-tailed) =0,329. Karena Asymp. Sig. (2-tailed) =0,329> a = 5\% maka H0 diterima. Ini berarti tidak terdapat perbedaan aspek timbulnya kartu kredit macet antara BNI dan BNI Syariah.Aspek timbulnya kartu kredit macet pada BNI adalah sama denganBNISyariah karena nilai "mean rank" pada output Mann Whitney Ranks 6,40 sedangkan nilai mean rankpadaBNI Syariah sebesar 4,60, sehingga tidak terdapat perbedaan signifikan. 


\section{Pembahasan}

Berdasarkan hasil uji, dapat di simpulkan bahwa baik BNI maupun BNI Syariah dapat dikatakan tidak terdapat perbedaan yang signifikan terhadap persepsi analis kartu kredit tentang resiko kartu kredit. Mean rank tertinggi dimiliki oleh BNI sebesar 6,40 pada variabel timbulnya kartu kredit macet, sementara mean rank BNI Syariah sebesar 4,60, hal ini menunjukkan bahwa BNI lebih unggul daripada BNI Syariah dalam penentuan timbulnya kartu kredit macet, namun keunggulannya tersebut tidak signifikan.

\section{Kesimpulan}

Penelitian ini dilakukan terhadap BNI dan BNI Syariah.Tujuan yang diharapkan dapat dicapai dalam penelitian ini adalah mengetahui apakah terdapat perbedaan yang signifikan antara persepsi analis kredit tentang resiko kartu kredit pada bank konvensional dan bank syariah.Bank Konvensional yang digunakan dalam penilitian ini adalah BNI dan BNI Syariah.Berdasarkan hasil pengolahan dan analis data yang dilakukan maka peneliti menarik beberapa kesimpulan.

Hasil stastistik menunjukkan dalam hal proses penerapan manajemen resiko, identifikasi resiko kredit dan timbulnya kartu kredit macet pada BNI dan BNI Syariah tidak terdapat perbedaan yang signifikan, hal ini menurut penulis wajar, karena memang tidak terdapat perbedaan manajemen dalam memberikan fasilitas kartu kredit pada BNI.

\section{Keterbatasan}

Dalam penelitian ini memiliki banyak keterbatasan, beberapa diantaranya adalah penelitian ini hanya melihat perbedaaan persepsi analis kartu kredit pada kantor wilayah BNI Semarang saja karena analis kartu kredit BNI di Jateng dan DIY terpusat di Semarang, sedangkan analis kartu kredit BNI Syariah diproses di kantor wilayah BNI Semarang juga, namun atas persetujuan analis kartu kredit BNI Syariah di Jakarta.

\section{Saran}

Berdasarkan kesimpulan di atas saran yang diajukan peneliti adalah

(1) Bagi Penulis

Agar mengkomunikasikan hasil penelitiannya sehingga dapat digunakan sebagai referensi untuk penelitian selanjutnya.

(2) Bagi Perusahaan/Instansi

Agar dapat memperhatikan prinsip-prinsip syariah dalam proses persetujuan kartu kredit pada bank syariah.

(3) Bagi Akademisi

Penelitian selanjutnya sebaiknya dilakukan untuk responden yang lebih luas, sehingga bukan hanya analis kartu kreditnya saja mungkin team processing nya juga bisa diikutsertakan untuk dijadikan sampel penelitian. Perlu dilakukan penelitiandengan menggunakan variabel-variabel yang lain, misalnya: lama proses persetujuan kartu kredit, jumlah nasabah pemohon kartu kredit, dII 


\section{DAFTAR PUSTAKA}

Alia, Husnah dan Rizal Yaya. 2006. Persepsi Analis Kredit Bank Konvensional dan Bank Syariah terhadap Akuntansi dalam Perfektif Syariah. Jakarta.

Arifin, Zainul. 2000. Memahami Bank Syariah. Alvabet: Jakarta.

Asnita. 2004. Persepsi Akuntan Pendidik dan Mahasiswa Akuntansi Terhadap Tujuan dan Karakteristik Akuntansi Islam. Skripsi. Universitas Sebelas Maret.

Hamidin, Aep S. 2010. Tips \& Trik Kartu Kredit: Memaksimalkan Manfaat dan Mengelola Risiko Kartu Kredit. Yogyakarta: Media Pressindo.

Harahap, Sofyan Safri. 2007. Akuntansi Perbankan Syariah Edisi Revisi. Universitas Trisakti: Jakarta.

http://bni.co.id

http://bnisyariah.co.id

Irmayanto, Juli. 2004. Bank dan Lembaga Keuangan Cetakan IV. Universitas Trisakti: Jakarta.

Khaeruddin, Widyanti. 2012. Analisis Kartu Kredit Syariah Pada PT Bank Negara Indonesia. Jurnal. Fakultas Ekonomi dan Bisnis Universitas Hasanuddin Makassar.

Lapoliwa, Nurumi. 2000. Akuntansi Perbankan Jilid I. Institut Bankir Indonesia: Jakarta.

Marissa, Ardiana. 2011. Analisis Perbandingan Kinerja Keuangan Bank Syariah dan Bank Konvensional Sebelum,

Selama dan Sesudah Krisis Tahun 2008 dengan Menggunakan Analisis Camel. Skripsi. Semarang Fakultas Ekonomika dan Bisnis Universitas Diponegoro.

Prasetyo, Indra. 2008. Analisis Kinerja Keuangan Bank Syari'ah Dan Bank Konvensional Di Indonesia. Jurnal. Fakultas Ekonomi Universitas Wijaya Putra Surabaya.

Rival, Veithzal. 2007. Bank and Financial Institution Management Conventional \& Sharia System. Raja Grafindo Persada: Jakarta.

Santoso, Singgih. 2004. SPSS mengelola data statistik secara profesional. PT. Elexmedia Komputindo. Jakarta.

Sudarsono, Heri. 2004. Bank dan Lembaga Keuangan Syariah Edisi 2. Ekonisia: Yogyakarta.

Sulaiman, Abdul Wahab Ibrahim Abu. 2006. Banking Cards Syariah Kartu Kredit dan Debit dalam Perspektif Fiqih.

Terjemahan oleh Aidil Novia. Ed.1.Jakarta: PT RajaGrafindo Persada.

Sunaryo. 2009. Hukum Lembaga Pembiayaan. Edisi 1, Cet. Ke-2. Jakarta: Sinar

Grafika.

Zarkasyi, Abdullah S. 2003. Managemen Resiko Kredit.http://www.google.com/search

Zarkasyi, Abdullah S. 2007. Modul Laboratorium Alat Analisis Kuantitatif. Universitas Trisakti Fakultas Ekonomi. 
JURNAL AKUNTANSI INDONESIA

\section{LAMPIRAN}

Tabel 1

Perbedaan Bank Syariah Dan Bank Konvensional

\begin{tabular}{ll}
\hline Bank Konvensional & Bank Syariah \\
\hline $\begin{array}{l}\text { Tidak membedakan investasi haram dan } \\
\text { halal }\end{array}$ & Hanya membiayai investasi yang halal saja \\
\hline $\begin{array}{l}\text { Pendapatan dari selisih bunga pinjman dan } \\
\text { bunga tabungan }\end{array}$ & $\begin{array}{l}\text { Pendapatan bank berdasarkan prinsip bagi } \\
\text { hasil, sewa, jual-beli }\end{array}$ \\
\hline $\begin{array}{l}\text { Kepentingan sepihak dan semata-mata } \\
\text { mengejar keuntungan }\end{array}$ & $\begin{array}{l}\text { Berorientasi kepentingan bersama dan tidak } \\
\text { mengejar keuntungan }\end{array}$ \\
\hline $\begin{array}{l}\text { Semata-mata karena hubungan bisnis } \\
\text { Hubungan kekeluargaan dan kemitran antara } \\
\text { pemilik bk dan pengguna dana }\end{array}$ \\
\hline $\begin{array}{l}\text { Diawasi Bank Indonesia } \\
\text { sektor moneter }\end{array}$
\end{tabular}

Tabel 2

Perbedaan Sistem Bunga dan Bagi Hasil

\begin{tabular}{ll}
\hline \multicolumn{1}{c}{ Bunga } & \multicolumn{1}{c}{ Bagi Hasil } \\
\hline $\begin{array}{l}\text { Penentuan bunga dibuat pada waktu akad } \\
\text { dengan asumsi harus selalu untung. }\end{array}$ & $\begin{array}{l}\text { Penentuan besarnya nisbah bagi hasil dibuat } \\
\text { pada waktu akad dengan berpedoman pada } \\
\text { kemungkinan untung-rugi }\end{array}$ \\
\hline $\begin{array}{l}\text { Besarnya bunga adalah suatu persentase } \\
\text { tertentu terhadap besarnya uang yang } \\
\text { dipinjamkan }\end{array}$ & $\begin{array}{l}\text { Besarnya bagi hasil adalah berdasarkan nisbah } \\
\text { terhadap besarnya keuntungan yang diperoleh. }\end{array}$ \\
\hline
\end{tabular}

Besarnya bunga tetap seperti yang dijanjikan tanpa mempertimbangkan apakah proyek/ usaha yang dijalankan oleh nasabah / mudharib untung atau rugi.
Besarnya bagi hasil tergantung pada keuntungan proyek/ usaha yang dijalankan. Bila usaha merugi maka kerugian akan ditanggung oleh pemilik dana, kecuali kerugian karena kelalaian, salah urus, atau pelanggaran oleh mudharib

Eksistensi bunga diragukan (kalau tidak dikecam)

oleh semua agama termasuk Islam

Tidak ada yang meragukan keabsahan bagi-hasil.

Sumber: Antonio (2001), Bank Syari'ah: Dari Teori ke Praktek (Gema Insani Press bekerja sama dengan Yayasan Tazkia Cendekia) 
Tabel 4

Lama Bekerja Responden

\begin{tabular}{cccc}
\hline \multirow{2}{*}{ Keterangan } & \multicolumn{2}{c}{ Analis Kartu Kredit } & \multirow{2}{*}{ Total } \\
\cline { 2 - 4 } & BNI & BNI Syariah & \\
\hline Lama Kerja & Jumlah & Jumlah & Jumlah \\
\hline Kurang dari 5 th & 2 & 3 & 5 \\
\hline Antara 5 s/d 10 th & 2 & 2 & 4 \\
\hline Lebih dari 10 th & 1 & 0 & 1 \\
\hline Total & 5 & 5 & 10 \\
\hline
\end{tabular}

Sumber : Data Primer

Tabel 5

Statistik Deskriptif Perbedaan Manajemen Resiko Kartu Kredit, Identifikasi Resiko Kartu Kredit dan Timbulnya Kartu Kredit Pada BNI dan BNI Syariah

Ranks

\begin{tabular}{lcccc}
\hline & Bank & $\mathrm{N}$ & Mean Rank & Sum of Ranks \\
\hline Manajemen Resiko KK & BNI & 5 & 6.00 & 30.00 \\
\cline { 2 - 5 } & BNISyariah & 5 & 5.00 & 25.00 \\
\cline { 2 - 5 } & Total & 10 & 4.80 & 24.00 \\
\hline Identifikasi Resiko KK & BNI & 5 & 6.20 & 31.00 \\
\cline { 2 - 5 } & BNISyariah & 5 & 6.40 & 32.00 \\
\cline { 2 - 5 } & Total & 10 & 4.60 & 23.00 \\
\hline
\end{tabular}

Manajemen Resiko KK Identifikasi Resiko KK Timbulnya Kkmacet

\begin{tabular}{lccc}
\hline Mann-Whitney U & 10.000 & 9.000 & 8.000 \\
\hline Wilcoxon W & 25.000 & 24.000 & 23.000 \\
\hline Z & -.535 & -.738 & -.976 \\
\hline Asymp. Sig. (2-tailed) & .592 & .461 & .329 \\
\hline Exact Sig. [2*(1-tailed Sig.)] & $.690^{\mathrm{a}}$ & $.548^{\mathrm{a}}$ & $.421^{\mathrm{a}}$
\end{tabular}

a. Not corrected for ties.

b. Grouping Variable: bank 
Jurnal Akuntansi Indonesia 